\title{
Introduction of sugar cane bagasse pellets in diets devoid of long fiber for feedlots finished steers
}

\author{
Inclusão de bagaço de cana-de-açúcar peletizado em dietas \\ desprovidas de fibra longa para tourinhos terminados em \\ confinamento
}

\author{
Mikael Neumann'; Robson Kyoshi Ueno²*; Letícia Farias Perussolo; \\ Luiz Fernando Menegazzo Gheller ${ }^{3}$; Mateus Poczynek ${ }^{3}$; \\ Júlio Otávio Jardim Barcellos ${ }^{4}$; Valter Harry Bumbieris Junior ${ }^{5}$
}

\begin{abstract}
The use of diets without roughage in beef feedlot has become common in recent years due to practicality, feasibility and availability of inputs. However, the introduction of roughage that does not harm the operation of the feeding management can bring health benefits to animals and economic gain. This study aimed to evaluate the productive and economic performance of steers finished in feedlot, fed three levels of sugar cane bagasse pellets (SBP) in diets without long-fiber. The treatments consisted of $0 \%, 7 \%$ and $14 \%$ of SBP in a mixture of concentrate, comprising $80 \%$ whole corn grain plus $20 \%$ of a protein core. The experimental design was completely randomized with four replications. The diet with $0 \%$ of SBP promoted lower dry matter intake and weight gain. Feed conversion was similar between treatments, with an average of $6.21 \mathrm{~kg}-1$. The lower dry matter digestibility was found in the diet with $14 \%$ of SBP. The introduction of SBP did not change the rumination, averaging 1.9 hours day-1. Animals fed 7\% of SBP showed higher fat thickness. Due to the numerical differences between treatments for feed conversion in housing and daily cost of food, the profit margin was maximal in the diet with $0 \%$ of SBP, with values of $\mathrm{R} \$ 338.1 ; \mathrm{R} \$ 311.6$ and $\mathrm{R} \$ 305,1$ per animal, respectively $0 \%, 7 \%$ and $14 \%$ of SBP. The introduction of SBP promoted improvements in production performance, but did not improve the economic results of steers finished in feedlot.
\end{abstract}

Key words: $100 \%$ concentrate diet. All concentrate diet. Co-products. High-grain diet. Whole corn grain.

\section{Resumo}

O uso de dietas sem volumoso no confinamento de bovinos tornou-se comum nos últimos anos devido à praticidade, viabilidade e disponibilidade de insumos. Entretanto, a inclusão de um volumoso que

\footnotetext{
${ }^{1}$ Prof., Programa de Pós-Graduação em Ciências Veterinárias, Saúde e Produção Animal Sustentável da Universidade Estadual do Centro-Oeste, UNICENTRO, Guarapuava, PR, Brasil. E-mail: neumann.mikael@hotmail.com

${ }^{2}$ Discente de Doutorado, Programa de Pós-Graduação em Zootecnia da Universidade Federal do Rio Grande do Sul, UFRGS, Porto Alegre, RS, Brasil. E-mail: robsonueno@hotmail.com

${ }^{3}$ Médicos Veterinários, Universidade Estadual do Centro Oeste, UNICENTRO, Guarapuava, PR, Brasil. E-mail: leticiaperussolo@, outlook.com; luizmenegazzogheller@hotmail.com; mateusmedvet@gmail.com

${ }^{4}$ Prof., Programa de Pós-Graduação em Zootecnia, UFRGS, Porto Alegre, RS, Brasil. E-mail: julio.barcellos@ufrgs.br

5 Prof. Dr., Programa de Pós-Graduação em Ciência Animal da Universidade Estadual de Londrina, UEL, Londrina, PR, Brasil. E-mail: jrbumbieris@uel.br

* Author for correspondence
} 
não prejudique a operacionalidade do manejo alimentar pode trazer benefícios sanitários aos animais e ganho econômico. Objetivou-se avaliar o desempenho produtivo e econômico de tourinhos terminados em confinamento, alimentados com três teores de pellets de bagaço de cana-de-açúcar (PBC) em dietas sem fibra longa. Os tratamentos eram compostos por $0 \%, 7 \%$ e $14 \%$ de $\mathrm{PBC}$ em uma mistura de alimentos concentrados, composta por $80 \%$ de grãos de milho inteiro mais $20 \%$ de um núcleo proteico. $\mathrm{O}$ delineamento experimental foi inteiramente ao acaso com quatro repetições. A dieta com $0 \%$ de PBC promoveu menor consumo de matéria seca e ganho de peso vivo. A conversão alimentar foi semelhante entre os tratamentos, apresentando média de $6,21 \mathrm{~kg} \mathrm{~kg}^{-1}$. A menor digestibilidade da matéria seca foi encontrada na dieta com 14\% de PBC. A inclusão de PBC não alterou o tempo de ruminação, com média de 1,9 horas dia $^{-1}$. Animais alimentados com 7\% de PBC apresentaram maior espessura de gordura. Devido às diferenças numéricas entre os tratamentos para a conversão alimentar em carcaça e custo diário com alimentação, a margem de lucro foi máxima na dieta com $0 \%$ de $\mathrm{PBC}$, apresentando valores de $\mathrm{R} \$ 338,1$; $\mathrm{R} \$ 311,6$ e $\mathrm{R} \$ 305,1$ por animal, respectivamente para $0 \%$, 7\% e 14\% de PBC. A inclusão de $\mathrm{PBC}$ promoveu melhorias no desempenho produtivo, porém não melhorou o resultado econômico de tourinhos terminados em confinamento.

Palavras-chave: Dieta 100\% concentrado. Dieta de alto grão. Dieta totalmente concentrada. Coprodutos. Grão de milho inteiro.

\section{Introduction}

The diet composition of Brazilian beef cattle has seen an increase in proportion of food concentrates in the past years, reflecting the relationship between the prices of commodities involved in feedlot operations. From 2010 onwards, the association between corn and fat beef was so favorable that the use of diets lacking roughage, where corn makes up the majority of the feed, became popular.

Non-roughage diets, with whole corn grains (WCG), are more commonly found in feedlots of the United States, Argentina and Uruguay, used when the market is favorable, when labor barriers are found or upon shortage of forage. According to Turgeon et al. (2010), introducing roughage reduces the diet's energetic density, increases the cost per unit of metabolizable energy, and complicates the feeding operation and feedlot management. Nevertheless, roughage is provided in finishing diets, even if in small quantities $(<10 \%$ of the diet), to maintain the rumen's health and to reduce the incidence of digestive disorders, such as bloat, acidosis, liver abscess and laminitis.

Roughage is the main responsible for ensuring the suitability of the diet's physical characteristics. In beef cattle, one important indicator in this context is the effective neutral detergent fiber (NDFe), which is the remaining percentage of neutral detergent fiber (NDF) that is retained in a 1.18-millimeter sieve. NDFe is the NDF fraction capable of stimulating salivation, chewing, rumination and rumen motility, which is responsible for maintaining the ruminal $\mathrm{pH}$ and health (PITT et al., 1996).

The levels of NDFe recommended for highenergy diets vary between $5 \%$ and $8 \%$. These values ensure that the rumen $\mathrm{pH}$ is maintained above the critical level of 5.7 without a drastic reduction in consumption (NRC, 2000). The roughage of finishing feeds can be replaced by WCG, which promotes a slower rate of starch availability for ruminal digestion than processed corn (TURGEON et al., 2010).

WCG may regulate starch fermentation and reduce the accumulation of acids in the rumen, mitigating digestive disorders. Katsuki (2009) calculated an NDFe value of $7.7 \%$ for the feed of young bulls in feedlots without roughage elements and with $85 \%$ of WCG. According to the author, and considering the NDFe theoretical concept, the NDFe was calculated considering $100 \%$ of NDF effectiveness in the WCG, which produces a sufficient stimulus for rumination and rumen motility, eliminating the need of long fiber contents in finishing feeds. 
Brazil produces approximately 642 million tons of sugar cane in little more than 9 million hectares. From those, 280 million tons are destined to sugar production and 360 million tons to alcohol production (CONAB, 2014). Sugar cane bagasse, derived from the juice extraction performed by the sugar-alcohol industry, is the greatest residue produced by the Brazilian agroindustry. Each ton of processed sugar cane generates an average of $280 \mathrm{~kg}$ of bagasse that is used as fuel for boilers, cellulose production and cattle feeding (ALCARDE, 2009).

The bagasse is dried and finely ground to form a pellet. Pelletizing reduces the particle size and increases forage density, compromising the food function that involves buffering the rumen $\mathrm{pH}$. Even when there is a high NDF content, the pellet disintegrates into miniscule particles within the rumen, providing the food with insignificant quantities of NDFe. This reduces the chewing and rumination activity, increasing the risk of acidosis (SALINAS-CHAVIRA et al., 2013).

Sugar cane bagasse pellets have been used as fuel for boilers. As they are easy to manipulate, occupy low storage space, can be smoothly transported given the high volumetric density, and do not show signs of aerobic decomposition, it may also be interesting to use them for feedlots. Not much is know about the use of sugar cane bagasse pellets in the diets of feedlots. Even with low NDFe, a high NDF content may help to maintain the rumen healthy, resulting in both productive and economical profits.

This study aimed to evaluate the productive and economical performance of finishing steers (in feedlots) fed with diets containing different levels of sugar cane bagasse pellets devoid of long fiber contents.

\section{Materials and Methods}

This work was performed at the Animal Production Center (NUPRAN) of the Midwestern State University (UNICENTRO), in Guarapuava, Paraná, Brazil. The region has a $\mathrm{Cfb}$ climate (subtropical mesothermal humid), with an average annual precipitation of $1.944 \mathrm{~mm}$, average annual minimum and maximum temperatures of $12.7{ }^{\circ} \mathrm{C}$ and $23.5^{\circ} \mathrm{C}$, respectively, and relative air humidity of $77.9 \%$, at an altitude of $1.026 \mathrm{~m}$. The experiment started on 30 August 2011 and ended on 04 December 2011.

Three levels of sugar cane bagasse pellets (SBP) were tested in the diets (lacking forage with long fiber - $100 \%$ concentrated) of steers in feedlots, at the finishing stage. Level zero consisted in a diet composed of $80 \%$ of whole corn grains and $20 \%$ of a mix of protein, vitamin and mineral (pelleted). The other treatments consisted of similar food components, to which $7 \%$ or $14 \%$ of SBP were added. Supplementary urea was provided in order to have iso-nitrogenated diets, as shown in Table 1.

Table 1. Participation of the feeds used in the diet trials.

\begin{tabular}{lccc}
\hline \multirow{2}{*}{ Composition of ingredients included on diet $(\% \mathrm{DM})$} & \multicolumn{3}{c}{ Levels of pellets } \\
\cline { 2 - 3 } & $0 \%$ & $7 \%$ & $14 \%$ \\
\hline Whole corn grains & 79.83 & 74.22 & 69.14 \\
Mix containing protein, vitamin and mineral & 20.17 & 18.50 & 16.84 \\
Sugar cane bagasse pellets & 0.00 & 6.95 & 13.40 \\
Additional urea & 0.00 & 0.32 & 0.63 \\
\hline
\end{tabular}

The following parameters were evaluated: daily dry matter intake (DMID, $\mathrm{kg}$ day $^{-1}$ ), dry matter intake in relation to body weight (DMIBW, \% of body weigh), average daily weight gain (ADG, $\mathrm{kg}$ 
day $^{-1}$ ), feed conversion (FC), ingestive behavior, apparent digestibility of the diet, characteristics of integrating and non integrating elements of the animals' carcass, and economy of the treatment. The experiment lasted 100 days. The first 16 days were meant for adaptation, followed by four sequential evaluation periods of 21 days. The animals were weighed at the beginning and end of each period, after a 12-hour fast for solids.

Twenty-four steers from the Brangus breed were used. All animals came from the same herd, had an average age of 12 months and an initial body weight (BW) of $364 \mathrm{~kg}$ (standard deviation of $14 \mathrm{~kg}$ ). The animals were distributed in a way that animal weight and body condition were equivalent between the experimental units. Twelve semi-covered 15 $\mathrm{m}^{2}$ confining pens were used. Each had a concrete feeder and a metallic drinker regulated by a floater valve.

Because the animals were used to a feed consisting of pasture with concentrated supplementation of $1 \% \mathrm{BW}$, the adaptation to the final diet was performed in a progressive manner. Corn silage without restrictions plus $1.2 \%$ of $\mathrm{BW}$ of the final diet were provided from days 1 to 4 . The final diet was supplemented in the proportions of $1.6 \%$ and $1.8 \%$ of the BW on days 5 and 9 , respectively. Silage supply was interrupted on day 13, when the final diet was provided freely. The evaluations started after day 16 .

Feed was provided two times per day, at $6 \mathrm{AM}$ and 5 PM. The daily consumption was registered by calculating the difference in weight between feed provided and respective leftovers. The supply was adjusted daily aiming to offer ad libitum feed, and considering $10 \%$ of dry matter (DM) leftovers.

During the experiment, food, diet and leftover samples were collected and analyzed for contents of crude protein (CP), mineral matter (MM), ethereal extract (EE), neutral detergent fiber (NDF) with the $\alpha$-amylase thermo stable enzyme and acid detergent fiber (ADF), according to methods described by Silva and Queiroz (2006). Total digestible nutrient content (TDN) was calculated according to the equations proposed by Weiss et al. (1992).

Table 2 shows the food analyses results. The protein, vitamin and mineral mix was fabricated with the following ingredients: soybean meal, soybean hulls, barley root, barley grains, corn grains, corn-germ, calcitic lime, dicalcium phosphate, cattle urea, common salt, vitamin and mineral premix and sodium monensin $\left(80 \mathrm{mg} \mathrm{kg}^{-1}\right)$.

Table 2. Bromatological composition of feeds and experimental diets.

\begin{tabular}{|c|c|c|c|c|c|c|c|c|c|c|}
\hline \multirow{2}{*}{ Feeds } & \multicolumn{10}{|c|}{ Bromatological results $(\% \text { of DM })^{1}$} \\
\hline & $\mathrm{DM}$ & $\mathrm{CP}$ & TDN & $\mathrm{EE}$ & MM & ADF & NDF & NDFe & NDFfo & NDFefo \\
\hline Whole corn grain & 89.55 & 8.23 & 85.17 & 3.73 & 3.12 & 3.22 & 9.61 & $9.61^{2}$ & - & - \\
\hline Protein mix & 90.58 & 36.4 & 61.76 & 2.34 & 5.35 & 8.14 & 14.36 & - & - & - \\
\hline Sugar cane bagasse pellets & 93.70 & 1.93 & 42.66 & 1.81 & 5.21 & 70.96 & 84.70 & $17.87^{3}$ & - & - \\
\hline Urea & 100.0 & $281.0^{4}$ & - & - & - & - & - & - & - & - \\
\hline \multicolumn{11}{|l|}{ Diets (pellets) } \\
\hline $0 \%$ & 89.76 & 13.91 & 80.45 & 3.45 & 3.57 & 4.21 & 10.57 & 7.67 & 0.00 & 0.00 \\
\hline $7 \%$ & 90.06 & 13.88 & 77.61 & 3.33 & 3.67 & 8.83 & 15.68 & 8.38 & 5.89 & 1.24 \\
\hline $14 \%$ & 90.35 & 13.84 & 75.00 & 3.22 & 3.76 & 13.10 & 20.41 & 9.04 & 11.35 & 2.39 \\
\hline
\end{tabular}


Sodium monensin was added to the diets not only to improve performance, but also because the NRC (2000) recommends the use of ionophores in highly energetic diets with a NDFe content varying between $5 \%$ and $8 \%$ of $\mathrm{DM}$, as an attempt to maintain the rumen $\mathrm{pH}$ above 5.7.

The ingestive behavior was evaluated on the fiftieth day after the experiment started. Observations were made during a continuous period of 72 hours. One observer per pen performed the measurements and registered the behavior activities every three minutes. The times spent in leisure, rumination, drinking (water ingestion) and feeding were measured (hours per day). Frequency of feeding activities (number of times per day), drinking, urination and defecation, were also annotated.

Concomitantly, apparent digestibility of DM in the experimental diets was evaluated. The whole production of feces for each experimental unit was collected, weighed and sampled in each of the 6 hours shift. After 72 hours of collection, the feces were homogenized to form a composite sample for dehydration, which allowed determining the apparent digestibility (AD) using the expression: $\mathrm{AD}(\%)=[(\mathrm{g}$ of consumed DM $-\mathrm{g}$ of excreted $\mathrm{DM})$ $\div$ g of consumed DM] x 100. This formula used the DMID from the same days of excreta collection, as the animals consumed the experimental feeds for fifty consecutive days.

At the end of the confinement period, and after the 12-hour fast for solids, the animals were weighed upon fridge loading (which was located at a $5 \mathrm{~km}$ distance). Normal slaughterhouse proceedings were used, in agreement with the legislation for bovine slaughtering.

Four development measurements were performed in the warm carcasses: carcass and arm lengths, arm perimeter and topside thickness, following the methods proposed by Muller (1987). The subcutaneous fat thickness was measured at the level of the $12^{\text {th }}$ rib and the non-integrating elements of the animals' carcass were weighed.
Carcass gain, carcass yield and carcass feed conversion were calculated considering $50 \%$ of carcass yield at the beginning of the experiment. The economic analysis considered the average regional prices from 2014: fat cattle at $\mathrm{R} \$ 8.02$ per $\mathrm{kg}$, corn at R\$23.87 per $60 \mathrm{~kg} \mathrm{sac}$, protein mix at $\mathrm{R} \$ 1218.42$ per ton, SBP at R\$ 238.70 per ton and cattle urea at R\$ 74.44 per $25 \mathrm{~kg}$ sac.

A random experimental design was used, composed of three treatments with four repetitions. Each repetition consisted of a pen with two animals. The variables were submitted to variance analysis and the averages were compared by Tukey's test, using a 5\% significance threshold. In addition, the performance variables were submitted to a polynomial regression analysis, where the four periods of 21 days were considered (total of 84 days). The data were analyzed using the statistical program SAS (1993).

This research project was approved by the ethics committee for animal use from the Midwestern State University (CEUA/UNICENTRO, protocol 028/2011).

\section{Results and Discussion}

Analysis of animal performance (Table 3) did not reveal interaction $(p>0.05)$ between the treatments and the confinement periods for DMID, DMIBW and FC. DMID increased linearly, while DMIBW decreased linearly throughout the days in confinement. FC worsened linearly over the periods.

An interaction $(p=0.031)$ between treatments and periods was detected for ADG. Seven percent of SBP in the feed produced a quadratic positive effect on ADG, while 14\% of SBP promoted a linear decrease as the confinement days progressed. The ADG regression equation was not significant for $0 \%$ of SBP (Table 3 ).

On average, the $0 \%$ SBP diet had lower DMID $(p<0.001)$, DMIBW $(p<0.001)$ and ADG $(p=0.048)$ than diets containing SBP. There was no difference in FC $(p=0.32)$ between treatments. 
Table 3. Performance of feedlot steers, fed diets devoid of long fiber containing levels of introduction of sugar cane bagasse pellets.

\begin{tabular}{|c|c|c|c|c|c|}
\hline \multirow{2}{*}{ Pellets levels } & \multicolumn{4}{|c|}{ Evaluation periods (days) } & \multirow{2}{*}{ Average } \\
\hline & $1^{\circ}(1-21$ days $)$ & $2^{\circ}$ (22-42 days) & $3^{\circ}(43-63$ days $)$ & $4^{\circ}$ (64-84 days) & \\
\hline \multicolumn{6}{|c|}{ Dry matter intake daily (DMID, $\left.\mathrm{kg} \mathrm{day}^{-1}\right)^{1}$} \\
\hline $0 \%$ & 7.89 & 8.08 & 8.65 & 9.11 & $8.43 \mathrm{~b}$ \\
\hline $7 \%$ & 8.25 & 9.54 & 9.68 & 9.91 & $9.35 \mathrm{a}$ \\
\hline $14 \%$ & 9.27 & 9.25 & 9.72 & 10.01 & $9.56 \mathrm{a}$ \\
\hline \multicolumn{6}{|c|}{ Dry matter intake (DMIBW, \% by BW) ${ }^{2}$} \\
\hline $0 \%$ & 2.02 & 1.92 & 1.92 & 1.89 & $1.94 \mathrm{~b}$ \\
\hline $7 \%$ & 2.11 & 2.23 & 2.08 & 1.99 & $2.10 \mathrm{a}$ \\
\hline $14 \%$ & 2.35 & 2.16 & 2.11 & 2.04 & $2.17 \mathrm{a}$ \\
\hline \multicolumn{6}{|c|}{ Feed conversion $\left(\mathrm{FC}, \mathrm{kg} \mathrm{kg}^{-1}\right)^{3}$} \\
\hline $0 \%$ & 4.93 & 6.91 & 5.33 & 7.25 & $6.11 \mathrm{a}$ \\
\hline $7 \%$ & 5.06 & 5.35 & 5.71 & 7.85 & $5.99 \mathrm{a}$ \\
\hline $14 \%$ & 5.24 & 6.74 & 6.15 & 7.97 & $6.52 \mathrm{a}$ \\
\hline \multicolumn{6}{|c|}{ Average daily weight gain (ADG, $\mathrm{kg}$ dia $^{-1}$ ) } \\
\hline $0 \%{ }^{4}$ & 1.611 & 1.190 & 1.667 & 1.270 & $1.434 \mathrm{~b}$ \\
\hline $7 \% 0^{5}$ & 1.635 & 1.857 & 1.698 & 1.278 & $1.617 \mathrm{a}$ \\
\hline $14 \%{ }^{6}$ & 1.794 & 1.397 & 1.603 & 1.357 & $1.538 \mathrm{a}$ \\
\hline
\end{tabular}

Means in column, followed by different lowercase letters, differ by $5 \%$ Tukey test.

Regression equations for periods (" $\mathrm{d} "=$ day 1 to 84$):{ }^{1} \mathrm{y}=8.11+0.0191 \mathrm{~d}\left(\mathrm{p}<0.001 ; \mathrm{R}^{2}=0.29 ; \mathrm{CV}=7.9\right) ;{ }^{2} \mathrm{y}=2.22-0.0029 \mathrm{~d}(\mathrm{p}=0.004$; $\left.\mathrm{R}^{2}=0.17 ; \mathrm{CV}=7.5\right) ;{ }^{3} \mathrm{y}=4.398+0.0345 \mathrm{~d}\left(\mathrm{p}<0.001 ; \mathrm{R}^{2}=0.35 ; \mathrm{CV}=18.5\right) ;{ }^{4}$ no significant $(\mathrm{p}=0.3839) ;{ }^{5} \mathrm{y}=1.122+0.032 \mathrm{~d}-0.0004 \mathrm{~d}^{2}$ $\left(\mathrm{p}=0.004 ; \mathrm{R}^{2}=0.55 ; \mathrm{CV}=12.9\right) ;{ }^{6} \mathrm{y}=1.814-0.0053 \mathrm{~d}\left(\mathrm{p}=0.092 ; \mathrm{R}^{2}=0.20 ; \mathrm{CV}=17.8\right)$.

Marques et al. (2011) tested the introduction of several levels of sugar cane bagasse (long fiber) in diets containing WCG for young Nelore bulls. Increasing the bagasse levels had a quadratic effect on DMID and a linear effect on ADG. DMID was 8.42 vs 10.51 vs $10.16 \mathrm{~kg} \mathrm{day}^{-1}$ for $0 \%$ (diet without forage), $3 \%$ and $6 \%$ of bagasse, respectively. ADG was 1.197 vs 1.587 vs $1.555 \mathrm{~kg} \mathrm{day}^{-1}$, for the respective levels. There was no difference in $\mathrm{FC}$, which had an average value of $6.730 \mathrm{~kg} \mathrm{~kg}^{-1}$.

Katsuki (2009) evaluated the introduction of several levels of soybean hulls $(0 \%, 15 \%, 30 \%$ and $45 \%$ ) in diets containing WCG without forage. He found that there was a quadratic effect on DMID, showing the following values: 6.99, 8.34, 9.63 and $9.25 \mathrm{~kg} \mathrm{day}^{-1}$, respectively. Even though there were no differences for $\mathrm{ADG}$ and $\mathrm{FC}$, the variation between treatments was noteworthy. ADG showed the following values: $0.953,1.278,1.440$ and 1.227 $\mathrm{kg} \mathrm{day}^{-1}$, and FC was 8.012, 6.740, 6.852 and 8.552 $\mathrm{kg} \mathrm{kg}^{-1}$, for the respective levels.

Both these studies were performed in animals of the Nelore breed and reported a lower ADG than the present study. This suggests that zebu cattle are less susceptibility to diets without forage (low NDF and/or pectin) than taurine or cross cattle. This includes WCG treatments without roughage, as reported by Marques et al. (2011), treatments without sugar cane bagasse, as reported by Katsuki (2009), and treatments without soybean hulls. Ueno (2012) showed that animals from the Canchim breed that were fed diets without forage with WCG had performances similar to those reported in this study, with an ADG of $1.564 \mathrm{~kg} \mathrm{day}^{-1}$ and a FC of $4.57 \mathrm{~kg} \mathrm{~kg}^{-1}$. 
The estimated TDN levels on the experimental diets (Table 2) and the lower DMID observed in animals treated with $0 \%$ of SBP suggest that the energetic density of this feed had a regulatory effect on animal DMID.

Krehbiel et al. (2006) computed data from 45 assays to assess the effects of increasing the energetic density in finishing diets. According to the authors, increasing the proportion of grains causes a reduction in DMID, a response that has been consistently described in the literature. Several hypotheses may explain this effect, but it seems that the mechanisms of chemotactic regulation or the potential increase in acid metabolites are what determine this consumption response. The increase of energetic density on the diet has an inversely proportional effect on DMID. On the other hand, the regression between consumption of metabolizable energy (ME) and energetic density on the diet is not significant, showing that finishing bovines consume DM to maintain a constant ME intake.

However, the same authors state that there is a cubic effect when ME consumption is evaluated in function of the increase in dietetic ME derived from grains. Animals that are fed low forage levels have a slightly higher ME consumption than those fed with completely concentrated diets, in agreement with the ME consumption data of this study (Table 4).

The linear decrease in DMIBW, observed over the confinement period, may indicate that animals adapt better to this chemotactic mechanism of regulation of feed consumption over time.

Table 4. Average feed consumption and neutral detergent fiber (NDF) for feedlot steers, fed diets devoid of long fiber containing levels of introduction of sugar cane bagasse pellets.

\begin{tabular}{lccc}
\hline \multirow{2}{*}{\multicolumn{1}{c}{ Feed intake $\left(\mathrm{kg}\right.$ of DM day $\left.{ }^{-1}\right)$}} & \multicolumn{3}{c}{ Pellets levels } \\
\cline { 2 - 4 } & $0 \%$ & $7 \%$ & $14 \%$ \\
\hline Whole corn grain & 6.73 & 6.94 & 6.61 \\
Protein mix & 1.70 & 1.73 & 1.61 \\
Sugar cane bagasse pellets & 0.00 & 0.65 & 1.28 \\
Adittional urea & 0.00 & 0.03 & 0.06 \\
\hline Metabolizable energy intake (Mcal day $\left.{ }^{-1}\right)^{1}$ & 24.53 & 26.18 & 25.91 \\
NDF intake (\% of average BW) & 0.20 & 0.33 & 0.44 \\
NDFfo intake (\% of average BW) & 0.00 & 0.12 & 0.25 \\
\hline
\end{tabular}

${ }^{1}$ Calculated by equation based on total digestible nutrient content of the diet (NRC, 2000).

Turgeon et al. (2010) infer that the DMIBW for finishing diets with little or no roughage is well predicted by the following equation: $1.906+$ $0.0199 *$ NDFfo (NDF from forage). Using the data from Table 2, the DMIBW values estimated by this equation are $1.91 \%, 2.02 \%$ and $2.13 \%$ for feeds with $0 \%, 7 \%$ and $14 \%$ of SBP, respectively, which is very similar to the averages observed in this study (see Table 3).
The consumption of metabolizable energy was similar to that described by Katsuki (2009), who reported 21.23, 23.78, 25.68 and 24.10 Mcal day ${ }^{-1}$ for diets without forage, with WCG and $0 \%, 15 \%$, $30 \%$ and $45 \%$ of soybean hulls (although the effect was not significant). NDF consumption by the BW showed an increasing linear effect, with values of $0.14,0.29,0.49$ and 0.67 , respectively. Both consumption of NDF and consumption of NDF 
derived exclusively from forage increased linearly (Table 4).

Table 5 shows that the diet with $14 \%$ of SBP had a lower apparent digestibility of DM. The introduction of SBP tended to increase manure production $(p=0.076)$ and rumination time $(\mathrm{p}=0.072)$.
Katsuki (2009) found that the introduction of soybean $(0 \%, 15 \%, 30 \%$ e $45 \%)$ caused a linear decrease in feed digestibility $(84.18 \%, 78.58 \%$, $65.42 \%$ and $69.23 \%$, respectively). Marques et al. (2011) reported that introducing $0 \%, 3 \%$ or $6 \%$ of sugar cane bagasse increased linearly the starch digestibility (respectively: $72.74 \%, 74.27 \%$ and $79.45 \%)$.

Table 5. Apparent digestibility and feeding behavior of feedlot steers, fed diets devoid of long fiber containing levels of introduction of sugar cane bagasse pellets.

\begin{tabular}{|c|c|c|c|c|}
\hline \multirow{2}{*}{ Evaluation } & \multicolumn{3}{|c|}{ Pellets levels } & \multirow{2}{*}{ Prob. } \\
\hline & $0 \%$ & $7 \%$ & $14 \%$ & \\
\hline Apparent digestibility of DM (\%) & $74.78 \mathrm{a}$ & $74.48 \mathrm{a}$ & $69.05 \mathrm{~b}$ & 0.008 \\
\hline Manure production ( $\mathrm{kg}$ of DM per animal day ${ }^{-1}$ ) & 2.05 & 2.47 & 2.70 & 0.076 \\
\hline \multicolumn{5}{|l|}{ Behavioral activities (hours day ${ }^{-1}$ ) } \\
\hline - Rumination time (hours day ${ }^{-1}$ ) & 1.58 & 1.95 & 2.18 & 0.072 \\
\hline - Leisure time (hours day ${ }^{-1}$ ) & 20.07 & 19.91 & 19.37 & 0.146 \\
\hline - Feeding time (hours day ${ }^{-1}$ ) & 2.11 & 1.96 & 2.27 & 0.266 \\
\hline - Drinking time (hours day ${ }^{-1}$ ) & 0.24 & 0.20 & 0.17 & 0.377 \\
\hline \multicolumn{5}{|l|}{ Behavioral activities (number of times per day ${ }^{-1}$ ) } \\
\hline - Feed & 16.56 & 13.78 & 16.11 & 0.073 \\
\hline - Drinking & 6.89 & 7.00 & 6.78 & 0.981 \\
\hline - Urination & $10.22 \mathrm{a}$ & $7.89 \mathrm{ab}$ & $6.44 \mathrm{~b}$ & 0.030 \\
\hline - Defecation & $6.89 \mathrm{~b}$ & $8.67 \mathrm{a}$ & $7.56 \mathrm{ab}$ & 0.036 \\
\hline
\end{tabular}

Means in line, followed by different lowercase letters, differ by $5 \%$ Tukey test.

Ueno (2012) found that finishing bovines fed with a WCG diet without forage exhibited periods of rumination of 1.28 hours day ${ }^{-1}$. Feeds with $45 \%$ corn silage promoted rumination periods of 7.17 hours day ${ }^{-1}$.

Salinas-Chavira et al. (2013) evaluated the effect of pelletized or chopped rice straw (at 5 or $10 \%$ of the $\mathrm{DM}$ ) in finishing diets. Ruminal $\mathrm{pH}$ was 5.2 and 5.7 for diets with pelletized and chopped straw, respectively. According to the authors, pelletizing increases the particle density, reducing total chewing activity, rumination time, and consequently ruminal $\mathrm{pH}$.

Animals fed with $0 \%$ of SBP had a greater frequency of daily urination, possibly due to higher daily consumption of water. Blood et al. (2002) states that bovines with sub-acute ruminal acidosis may ingest large quantities of water, especially after ingesting dry grains. This may occur due to the rise in concentration of ruminal lactic acid, which in turn increases the osmolarity and withdraws water from the circulating system, causing hemo-concentration and dehydration. 
The evaluation of the animals' carcass (Table 6), did not find differences in carcass weight between treatments. Carcass yield improved marginally for animals consuming a diet with $0 \%$ of SBP, but this difference was not significant.

Table 6. Carcass characteristics of feedlot finished steers, fed diets devoid of long fiber containing levels of introduction of sugar cane bagasse pellets.

\begin{tabular}{lcccc}
\hline \multirow{2}{*}{\multicolumn{1}{c}{ Variables }} & \multicolumn{3}{c}{ Pellets levels } & \multirow{2}{*}{ Prob. } \\
\cline { 2 - 4 } & $0 \%$ & $7 \%$ & $14 \%$ & 0.275 \\
\hline Body weight ranch $(\mathrm{kg})$ & 505.2 & 517.0 & 517.3 & 0.975 \\
Hot carcass weight $(\mathrm{kg})$ & 284.7 & 285.7 & 284.7 & 0.320 \\
Carcass yield (\%) & 56.3 & 55.2 & 55.0 & 0.009 \\
Fat thickness (mm) & $3.83 \mathrm{~b}$ & $6.33 \mathrm{a}$ & $4.33 \mathrm{~b}$ & 0.475 \\
Carcass length (cm) & 148.8 & 150.0 & 151.5 & 0.316 \\
Thigh thickness (cm) & 23.5 & 23.0 & 24.3 & 0.623 \\
Arm lenght (cm) & 37.7 & 38.0 & 37.5 & 0.795 \\
Arm perimeter (cm) & 40.9 & 40.3 & 40.0 & \\
\hline
\end{tabular}

Means in line, followed by different lowercase letters, differ by $5 \%$ Tukey test.

Thickness of the subcutaneous fat layer was greater for animals treated with a diet containing $7 \%$ of SBP. According to Krehbiel et al. (2006), this may be due to the greater ADG rates and ME consumption observed in this treatment (Table 4).

Work by Marques et al. (2011) showed that supplying $0 \%, 3 \%$ or $6 \%$ of sugar cane bagasse neither altered the carcass yield $(57.66 \%)$ nor the thickness of the subcutaneous fat layer $(4.85 \mathrm{~mm})$. Nevertheless, there was a linear increase in the weight of the warm carcass, with values of 273.91 vs 290.17 vs $293.85 \mathrm{~kg}$ for the respective levels.

Analysis of non-integrating elements of the animals' carcass (Table 7) showed differences only for the tongue $(\mathrm{p}<0.05)$. Animals fed with $0 \%$ of SBP had heavier tongues than those treated with $14 \%$ of SBP, possibly because diets with $0 \%$ of SBP have a lower volume, creating greater difficulties for food capture and demanding, therefore, greater utilization (exercise) of the tongue for ingestion, salivation and swallowing.

As described in Table 8, no differences were detected in animal carcass gain between treatments $(\mathrm{p}>0.05)$. However, the diet with $0 \%$ of SBP showed a tendency to produce greater $(p=0.16)$ yields in carcass gain (\% of ADG expressed in carcass) and a better $(\mathrm{p}=0.09)$ conversion of feed into carcass, compared to the diets with SBP.

The introduction of soybean hulls $(0 \%, 15 \%$, $30 \%$ and $45 \%$ ) in diets without forage with WCG did not influence carcass characteristics (KATSUKI, 2009). Average carcass weight was $297 \mathrm{~kg}$, average carcass yield was $55.18 \%$ and average fat thickness was $6.58 \mathrm{~mm}$. There was no effect on yield of carcass gain, which had the respective values of $85.40 \%, 85.86 \%, 76.09 \%$ and $75.35 \%$. 
Table 7. Non-integrating components of carcass of feedlot finishing steers, fed diets devoid of long fiber containing levels of introduction of sugar cane bagasse pellets.

\begin{tabular}{lcccc}
\hline \multicolumn{1}{c}{ Variables $(\mathrm{kg})$} & \multicolumn{3}{c}{ Pellets levels } & \multirow{2}{*}{ Prob. } \\
\cline { 2 - 4 } \multicolumn{1}{c}{ Head weight } & $0 \%$ & $7 \%$ & $14 \%$ & 0.387 \\
Tongue weight & $0.96 \mathrm{a}$ & 11.22 & 11.54 & 0.042 \\
Tail weight & 1.34 & 1.43 & $0.87 \mathrm{~b}$ & 0.184 \\
Heart weight & 1.56 & 1.70 & 1.30 & 0.072 \\
Liver weight & 6.02 & 6.04 & 6.31 & 0.312 \\
Kidneys weight & 0.99 & 1.04 & 1.00 & 0.387 \\
Lung weight & 6.87 & 7.36 & 7.11 & 0.222 \\
Spleen weight & 1.92 & 1.82 & 1.85 & 0.724 \\
Full rumen-reticulum weight & 39.13 & 36.55 & 38.43 & 0.634 \\
Empty rumen-reticulum weight & 10.06 & 10.56 & 10.80 & 0.610 \\
Full abomasum weight & 2.86 & 3.80 & 3.38 & 0.140 \\
Empty abomasum weight & 2.14 & 2.58 & 2.63 & 0.343 \\
Full intestine weight & 18.17 & 21.40 & 20.41 & 0.157 \\
Paws weight & 10.3 & 10.7 & 10.5 & 0.495 \\
Leather weight & 43.9 & 41.8 & 43.1 & 0.290 \\
Testicles weight & 1.18 & 1.47 & 1.29 & 0.113 \\
\hline
\end{tabular}

Means in line, followed by different lowercase letters, differ by $5 \%$ Tukey test.

Turgeon et al. (2010) performed 6 experiments comparing traditional finishing diets (with $4 \%$ to $10 \%$ of forage in the DM) with diets without forage with WCG (from $8 \%$ to $23 \%$ of WCG in the DM). Five of their assays showed that animals fed with forage suffer increases of $1.5 \%$ in their final weight, $3.7 \%$ in $\mathrm{ADG}$ and $5.7 \%$ in DMID, and have greater carcass gains. These assays also showed that the benefit of using diets without roughage is that they provide improvements in $\mathrm{FC}(3.5 \%)$ and in $\mathrm{FC}$ in the carcass ( 7.662 vs $\left.7.881 \mathrm{~kg} \mathrm{~kg}^{-1}\right)$, corroborating the data of this study. This study shows that the use of completely concentrated diets is an interesting alternative for producers who commercialize animals based on the carcass weight rather than on BW.

Table 8. Carcass gain and economic analysis of feedlot finishing steers, fed diets devoid of long fiber containing levels of introduction of sugar cane bagasse pellets.

\begin{tabular}{lcccc}
\hline \multirow{2}{*}{\multicolumn{1}{c}{ Variables }} & \multicolumn{3}{c}{ Pellets levels } & \multirow{2}{*}{ Prob. } \\
\cline { 2 - 3 } & $0 \%$ & $7 \%$ & $14 \%$ & 0,969 \\
Feedlot carcass gain (kg) & 97,45 & 98,15 & 96,78 & 0,159 \\
Carcass gain yield (\%) & 74,68 & 69,31 & 68,43 & 0,479 \\
Average daily carcass gain (kg) & 1,068 & 1,120 & 1,051 & 0,095 \\
Feed conversion in carcass (kg) & 7,893 & 8,381 & 9,145 & 0,202 \\
\hline Daily cost feed (R\$) & 5,28 & 5,66 & 5,61 & 0,202 \\
Feed feedlot cost (R\$) & 443,37 & 475,49 & 471,07 & 0,969 \\
Revenue of the carcass gain on feedlot (R\$) & 781,48 & 787,10 & 776,14 & 0,719 \\
Profit margin (R\$) & 338,11 & 311,61 & 305,06 & \\
\hline
\end{tabular}


Introducing SBP in the feed reduced the cost per $\mathrm{kg}$ of diet. The observed values were $0.63 \mathrm{vs}$ 0.61 vs $0.59 \mathrm{R} \$$ per $\mathrm{kg}$ of DM for $0 \%, 7 \%$ and $14 \%$ of SBP, respectively. However, due to variations in DMID, the supply of $7 \%$ or $14 \%$ of SBP tended to promote greater $(\mathrm{p}=0.20)$ daily costs of feeding, compared to the diet with $0 \%$ of SBP (Table 8 ).

The resemblance between gain in carcass weight for different treatments (Table 8) provided similar revenues for animal fattening. However, diets containing SBP showed a tendency for greater feeding costs. Thus, the diet with $0 \%$ of SBP had the better profit margins $(p=0.72)$, when deducting feeding costs.

\section{Conclusions}

The introduction of sugar cane bagasse pellets in diets devoid of long fiber contents for steers in finishing stages in feedlots increased feed consumption, gain in body weight and thickness of the subcutaneous fat layer. In addition, it tended to increase the rumination time and the daily cost of feeding. The better productive performance of animals fed $7 \%$ of pellets did not translate into a greater carcass weight.

Therefore, the introduction of sugar cane bagasse pellets in a diet devoid of long fiber improved the productive performance but not the economic results of steers finished in feedlots.

\section{Referências}

ALCARDE, A. R. Processamento da cana-de-açúcar: outros produtos. Brasília: Agência de informação da EMBRAPA, 2009. Disponível em: <http://www.agencia. cnptia.embrapa.br/gestor/cana-de-acucar/arvore/ CONTAG01_108_22122006154841.html>. Acesso em: 14 mar. 2015.

BLOOD, D. C.; HENDERSON, J. A.; RADOSTITS, O. M. Doenças do trato alimentar. In: RADOSTITS, O. M.; GAY, C. C.; BLOOD, D. C.; HINCHCLIFF, K. W. (Ed.). Clínica veterinária. 9. ed. Rio de Janeiro: Guanabara Koogan, 2002, p. 95-149.
COMPANHIA NACIONAL DE ABASTECIMENTO CONAB. Acompanhamento da safra brasileira de canade-açúcar. Brasília: CONAB, 2014. v. 1, n. 3, 27 p.

KATSUKI, P. A. Avaliação nutricional, desempenho e qualidade da carne de bovinos alimentados com rações sem forragem, com diferentes niveis de substituição do milho inteiro por casca de soja. 2009. Tese (Doutorado em Ciência Animal) - Universidade Estadual de Londrina, Londrina.

KREHBIEL, C. R.; CRANSTON, J. J.; McCURDY, M. P. An upper limit for caloric density of finishing diets. Journal of Animal Science, Champaign, v. 84, n. 13, p. 34-49, 2006. Supplement Special.

MARQUES, R. S.; DÓREA, J. R. R.; PEDROSO, A. M.; BISPO, A. W.; MARTINS, C. G.; ANGOLINI, W. F.; SANTOS, F. A. P. Effects of varying forage levels in diets containing whole flint corn and benefits of steam flaking the corn on finishing Nellore bulls performance, carcass characteristics, and liver abscesses. Journal of Animal Science, Champaign, v. 89, p. 761-765, 2011. Supplement 1.

MULLER, L. Normas para avaliação de carcaça e concurso de carcaças de novilhos. 2. ed. Santa Maria: Universidade Federal de Santa Maria, 1987. 31 p.

NATIONAL RESEARCH COUNCIL - NRC. Nutrient requirements of beef cattle. $7^{\text {th }}$ ed. Washington: National Academy of Sciences, 2000. 248 p.

PITT, R. E.; VAN KESSEL, J. S.; FOX, D. G.; PELL, A. N.; BARRY, M. C.; VAN SOEST, P. J. Prediction of ruminal volatile fatty acids end $\mathrm{pH}$ within the net carbohydrate and protein system. Journal of Animal Science, Champaign, v. 74, n. 1, p. 226-244, 1996.

SALINAS-CHAVIRA, J.; ALVAREZ, E.; MONTAÑO, M. F.; ZINN, R. A. Influence of forage NDF level, source and pelletizing on growth performance, dietary energetics, and characteristics of digestive function for feedlot cattle. Animal Feed Science and Technology, Amsterdam, v. 183, n. 3-4, p. 106-115, 2013.

STATISTICAL ANALYSIS SYSTEM INSTITUTE SAS Institute. SAS/STAT user's guide: statistics, version 6. 4. ed. North Caroline: SAS Institute, 1993. v. 2, 943 p.

SILVA, D. J.; QUEIROZ, A. C. de. Análise de alimentos: métodos químicos e biológicos. 3. ed. Viçosa, MG: UFV, 2006. 235 p.

TURGEON, O. A.; SZASZ, J. I.; KOERS, W. C.; DAVIS, M. S.; VANDER POL, K. J. Manipulating grain processing method and roughage level to improve feed efficiency in feedlot cattle. Journal of Animal Science, Champaign, v. 88, n. 1, p. 284-295, 2010. 
UENO, R. K. Avaliação bioeconômica da cultura do milho (Zea mays L.) utilizada sob diferentes formas na alimentação de novilhos em confinamento. 2012. Dissertação (Mestrado em Agronomia) - Universidade Estadual do Centro-Oeste, Guarapuava.
WEISS, W. P.; CONRAD, H. R.; ST. PIERRE, N. R. A theoretically based model for predicting total digestible nutrient values of forages and concentrates. Animal Feed Science and Technology, Amsterdam, v. 39, n. 1-2, p. 95110, 1992. 